\title{
Da antiga sede da Diretoria Geral de Saúde Pública (DGSP) ao atual Instituto Nacional do Câncer (Inca)
}

\author{
From the old headquarters of the Diretoria Geral de Saude \\ Pública (DGSP) to the Instituto Nacional do Câncer (Inca)
}

Benedito Tadeu de Oliveira

Diretor do Instituto do

Patrimônio Histórico e Artístico

Nacional (IPHAN) de Ouro

Preto.

Praça Tiradentes, 33

35.400-000 Ouro Preto - MG

Brasil

beneditoo@uaigiga.com.br
OLIVEIRA, Benedito T. de. Da antiga sede da Diretoria Geral de Saúde Pública (DGSP) ao atual Instituto Nacional do Câncer (Inca).

História, Ciências, Saúde - Manguinhos, Rio de Janeiro, v.14, n.1, p. 325-346, jan.-mar. 2007.

A antiga sede da Diretoria Geral de Saúde Pública (DGSP), localizada na rua do Resende, $\mathrm{n}^{\circ} 128$, e o conjunto arquitetônico histórico de Manguinhos, da Fundação Oswaldo Cruz (Fiocruz), são contemporâneos. Foram construídos por iniciativa de Oswaldo Cruz e projetados por Luiz Moraes Júnior. A antiga DGSP é tão importante quanto o Instituto Oswaldo Cruz (IOC), atual Fiocruz, na implantação e institucionalização das políticas de saúde pública no Brasil. Este trabalho descreve o projeto de construção do edifício da DGSP, sua evolução, as transformações por que passou e o processo de tombamento pelo patrimônio histórico.

PALAVRAS-CHAVE: edifício da Diretoria Geral de Saúde Pública; Morais Júnior, Luiz (engenheiro); Rio de Janeiro; arquitetura; patrimônio histórico.

OLIVEIRA, Benedito T. de. From the old headquarters of the Diretoria Geral de Saúde Pública (DGSP) to the Instituto Nacional do Câncer (Inca).

História, Ciências, Saúde - Manguinhos, Rio de Janeiro, v.14, n.1, p.325-346, Jan.-Mar. 2007.

The old headquarters of the Diretoria Geral de Saúde Pública (DGSP), located on Rua do Resende \#128, and the Conjunto Arquitetônico Histórico de Manguinhos da Fiocruz (Manguinhos-Fiocruz Historical Architectural Complex) are contemporary buildings built by the initiative of Oswaldo Cruz and projects by Luiz Moraes Júnior. The old DGSP is as important as the so-called Instituto Oswaldo Cruz (IOC) then, now Fundação Oswaldo Cruz (Fiocruz) for the introduction and institucionalization of public health policies in Brasil. We describe the building project of the DGSP facilities, its evolution, transformations, and the process of becoming part of the Historic Heritage.

KEYWORDS: Edifício da Diretoria Geral de Saúde Pública; Morais Júnior, Luiz (engineer); Rio de Janeiro; architecture; historic heritage. 


\section{Antecedentes históricos}

To século XVIII, a área hoje compreendida entre as ruas do 1 Resende (inicialmente denominada Caminho dos Arcos), do Senado, dos Inválidos e Riachuelo tinham em seu centro o morro do Senado (antigo morro de Pedro Dias), que era circundado por charcos e capinzais.

O marquês de Lavradio, vice-rei do Brasil (1769-1779), iniciou as obras de saneamento dos pantanais de Pedro Dias que ocupavam grande área da cidade, às quais deu continuidade outro vicerei (1790-1801), d. José Luís de Castro, o conde de Resende. Ele aterrou e drenou os brejos, abrindo as atuais ruas do Senado, dos Inválidos e do Resende. O historiador Vivaldo Coaracy (1988, p.360) relata a origem dos nomes dessas ruas que cortavam muitas chácaras. Afirma que o local em que foram erguidos os edifícios da Saúde Pública era conhecido como Chácara do Barros, por ter sido seu último proprietário Justiniano de Barros.

Já o historiador Brasil Gerson (2000, p.224) informa que, ao ser aberta, a rua do Resende não ia além da rua dos Inválidos. Tratava-se do antigo caminho conhecido como dos Arcos, e só recebeu seu nome atual a partir de 1798, em honra ao vice-rei que o abriu.

Em levantamentos urbanos de 1904, 1905 e 1908, além da existência da rua do Resende, notam-se projeções da antiga praça Vieira Souto, hoje Cruz Vermelha, da rua Paulo de Frontin, hoje Washington Luís, e da atual avenida Henrique Valadares.

Em 1902, Rodrigues Alves foi eleito presidente da República. Em manifesto à nação a 15 de novembro, destacou a necessidade de saneamento da capital federal e o comprometimento de seu governo com essa tarefa (Benchimol, 1990, p.23). Para executar a reforma urbana, foi nomeado prefeito o engenheiro Francisco Pereira Passos, e para coordenar a reforma sanitária, o jovem médico Oswaldo Gonçalves Cruz. Os dois foram dotados, por Rodrigues Alves, de poderes quase ditatoriais para a consecução das reformas, iniciadas em 1903 (Carvalho, 2000, p.93).

Em 23 de março, Oswaldo Cruz assumiu o cargo de diretorgeral da Saúde Pública, com a proposta de erradicar as três principais doenças pestilenciais do Rio de Janeiro: a febre amarela, a peste bubônica e a varíola. O novo diretor-geral considerava essencial, para atingir tais objetivos, a reforma dos serviços sanitários, a reorganização das regulamentações jurídicas visando ampliar o poder das autoridades sanitárias e a reestruturação e potencialização das infra-estruturas destinadas a implantar seu novo projeto de saúde pública. No seu primeiro mandato, de 1903 a 1906, Oswaldo Cruz iniciou uma grande remodelação arquitetônica no antigo Instituto Soroterápico Federal - hoje Fundação Oswaldo Cruz - e a 
1 O desinfectório realizava a desinfecção de casas, objetos pessoais etc. de doentes notificados de doenças contagiosas, e a remoção destes para os hospitais de isolamento determinados. construção da sede da Diretoria-Geral de Saúde Pública (DGSP), na rua do Resende, $\mathrm{n}^{\mathbf{0}} 128$.

Nos relatórios ministeriais apresentados ao ministro da Justiça e Negócios Interiores J.J. Seabra, em 1905, Oswaldo Cruz manifestava preocupação quanto à infra-estrutura da época e à política de saúde pública a ser adotada. Seu plano era a construção de edifícios que obedecessem aos "preceitos modernos da mais segura higiene", em diversos pontos da capital federal, "para atender de pronto aos serviços dos demais Distritos Sanitários". A cessão de "um magnífico terreno à Rua do Resende 118" - onde seria construído o edifício destinado ao Desinfectório Central ${ }^{1}$ da Inspectoria de Serviço de Isolamento e Desinfecção - e a aprovação da Comissão de Finanças para as obras foram motivos de júbilo para o novo diretor. (Relatórios..., 1905, anexo 2, p.3.) Desde 1892, na qualidade de membro do Conselho Distrital de Higiene Municipal, Oswaldo Cruz propusera

a divisão da zona urbana na Capital Federal em cinco grandes distritos, em cada um dos quais se assentaria convenientemente um desinfectório público, com aparelhos completos, ambulância para doentes, carros de condução para material e pessoal, e de transporte de roupas e de objetos, enfim, todo o necessário para um estabelecimento bem organizado; com anexos de desinfectórios, câmaras de banhos e fornos de incineração. (Cruz, 1906, p.37)

\section{O edifício-sede da DGSP}

Com a construção da sede da DGSP e de mais duas estações de desinfecção, o objetivo de Oswaldo Cruz era deixar a cidade "perfeitamente aparelhada para acudir com proveito a todos os serviços sanitários" (Cruz, 1906).

As obras foram iniciadas em 19 de novembro de 1905, com a derrubada do casario colonial existente no terreno, e as fundações, em julho de 1906. Para o início dos serviços e a execução das fundações, o Congresso votou cem contos em 1905 e outros cem contos no ano seguinte, registrados no "Relatório apresentado ao Sr. Dr. Diretor de Saúde Pública pelo Dr. Alfredo da Graça Couto, inspetor do Serviço de Isolamento e Desinfecção em 1906" (Relatórios..., 1906). Com o crédito destinado pelo Congresso, a Diretoria iniciou a construção do Desinfectório Geral, da sede da Repartição, do Laboratório Bacteriológico e dos setores de Demografia e Engenharia Sanitária.

O projeto foi encomendado ao arquiteto Luiz Moraes Júnior, que elaborou inicialmente alguns desenhos datados de 17 de outubro de 1905, reproduzidos a seguir. Esses desenhos constam do relatório apresentado por Oswaldo Cruz ao ministro da Justiça e Negócios Interiores, J.J. Seabra. 


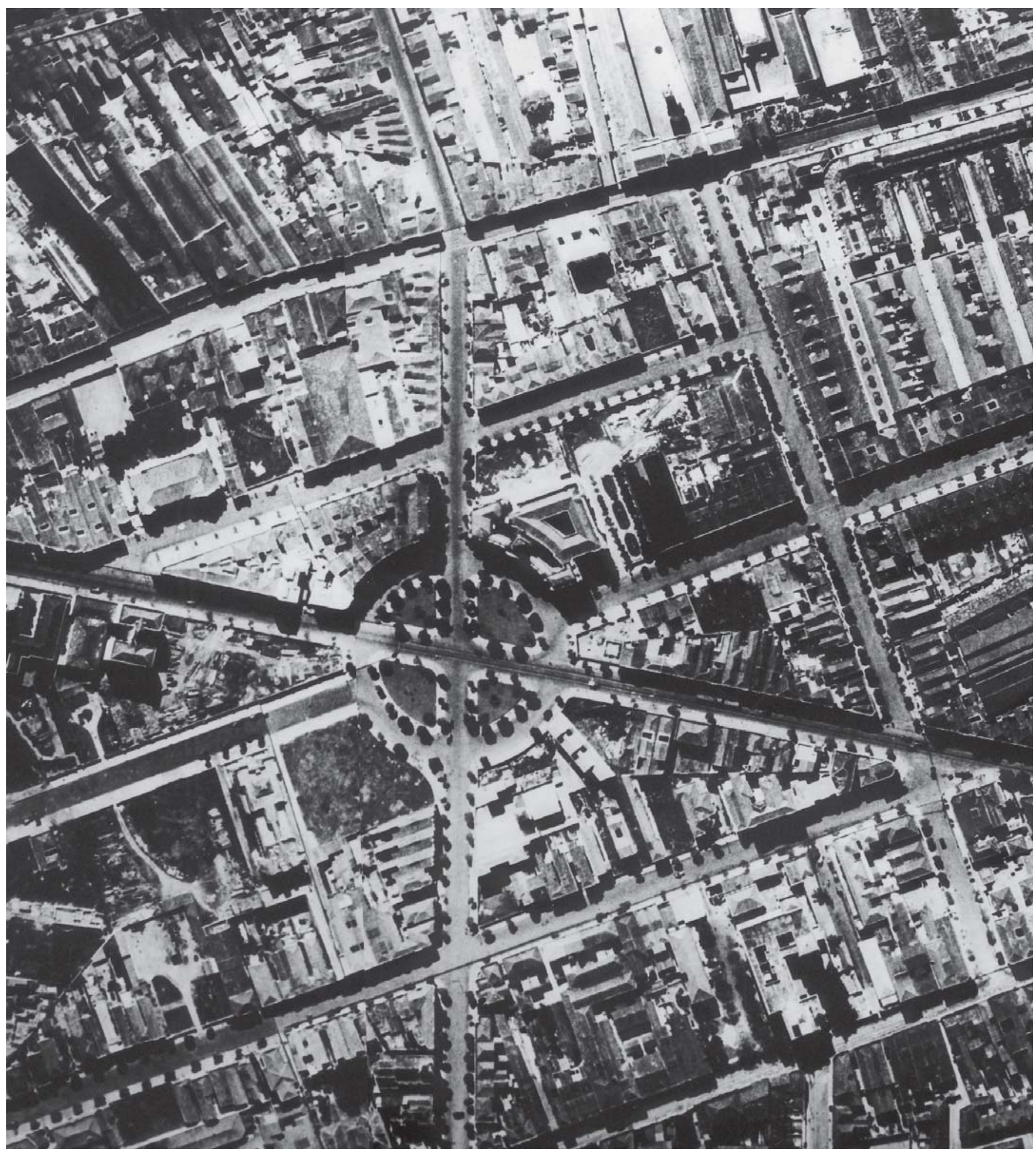

Figura 1: Fotografia aérea, s.d. Atual praça da Cruz Vermelha. AGCRJ, reprodução fotográfica de Marco Belandi 
DA ANTIGA SEDE DA DIRETORIA GERAL DE SAÚDE PÚBLICA...

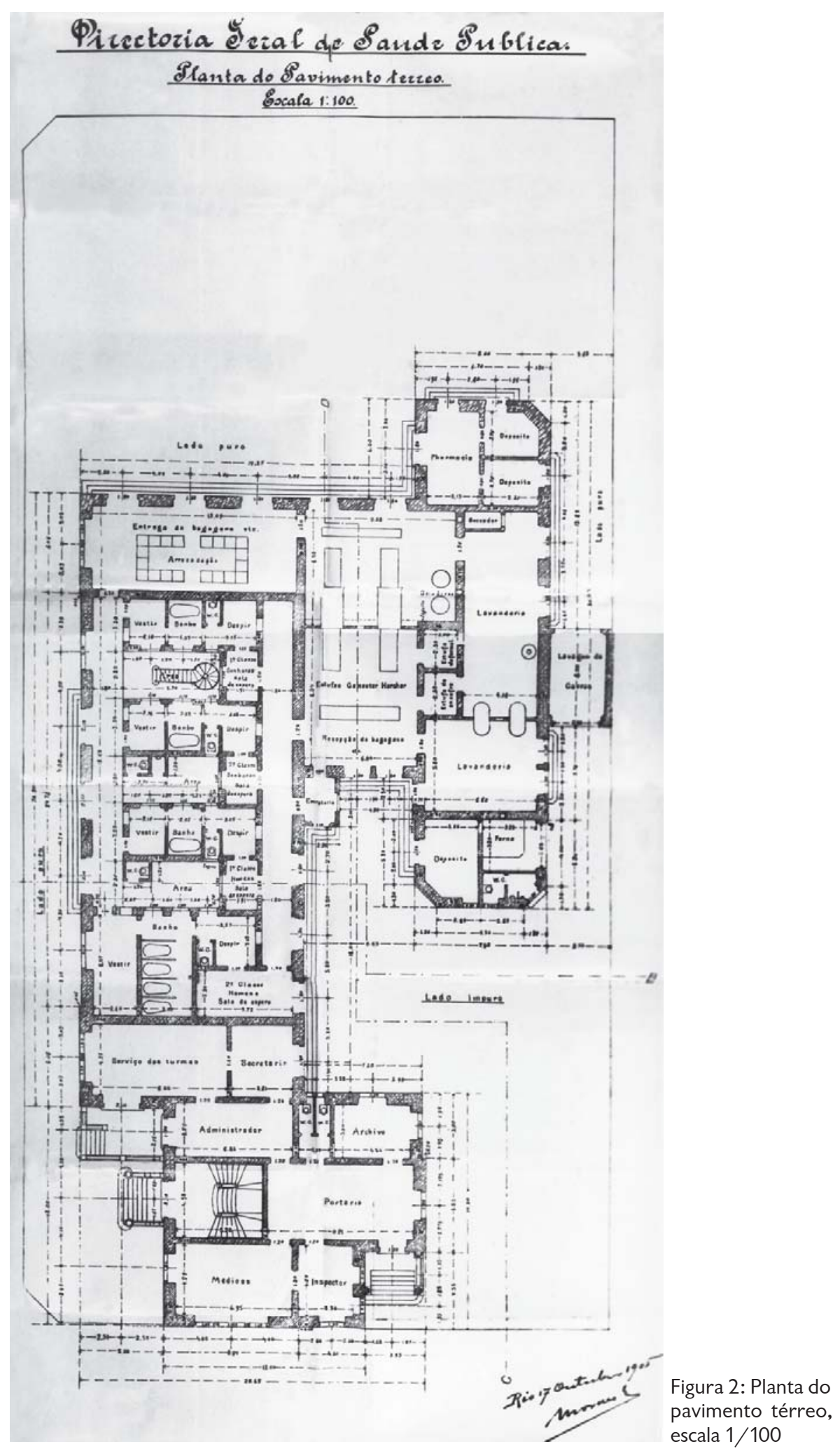


BENEDITO TADEU DE OLIVEIRA

\section{Directoria Seral Se Saude Publisa}

Slanta do 1: andar Escala 1:100

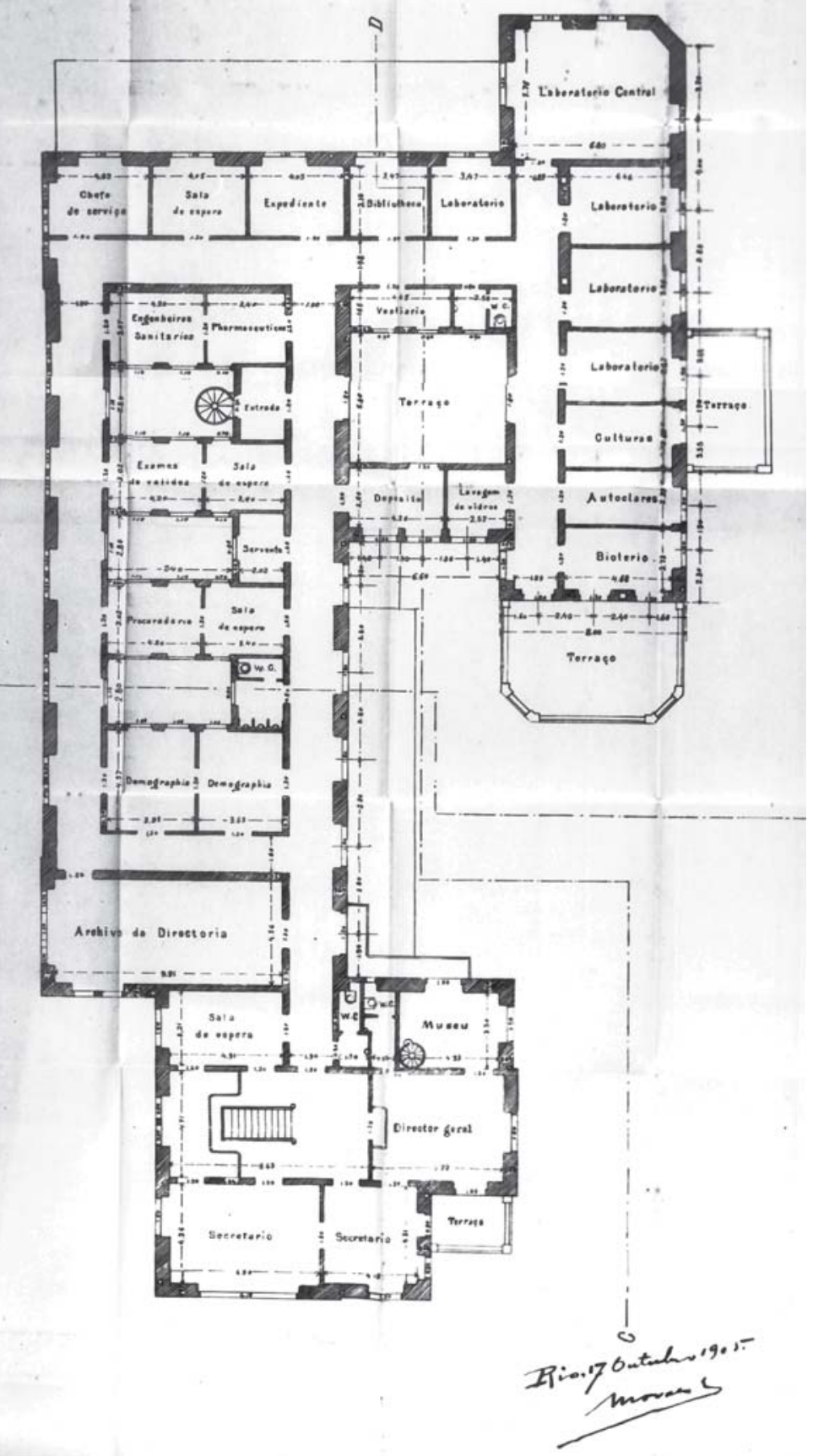

Figura 3: Planta do primeiro andar, escala $1 / 100$ 


\section{Directoria Geral de Saride Publica}

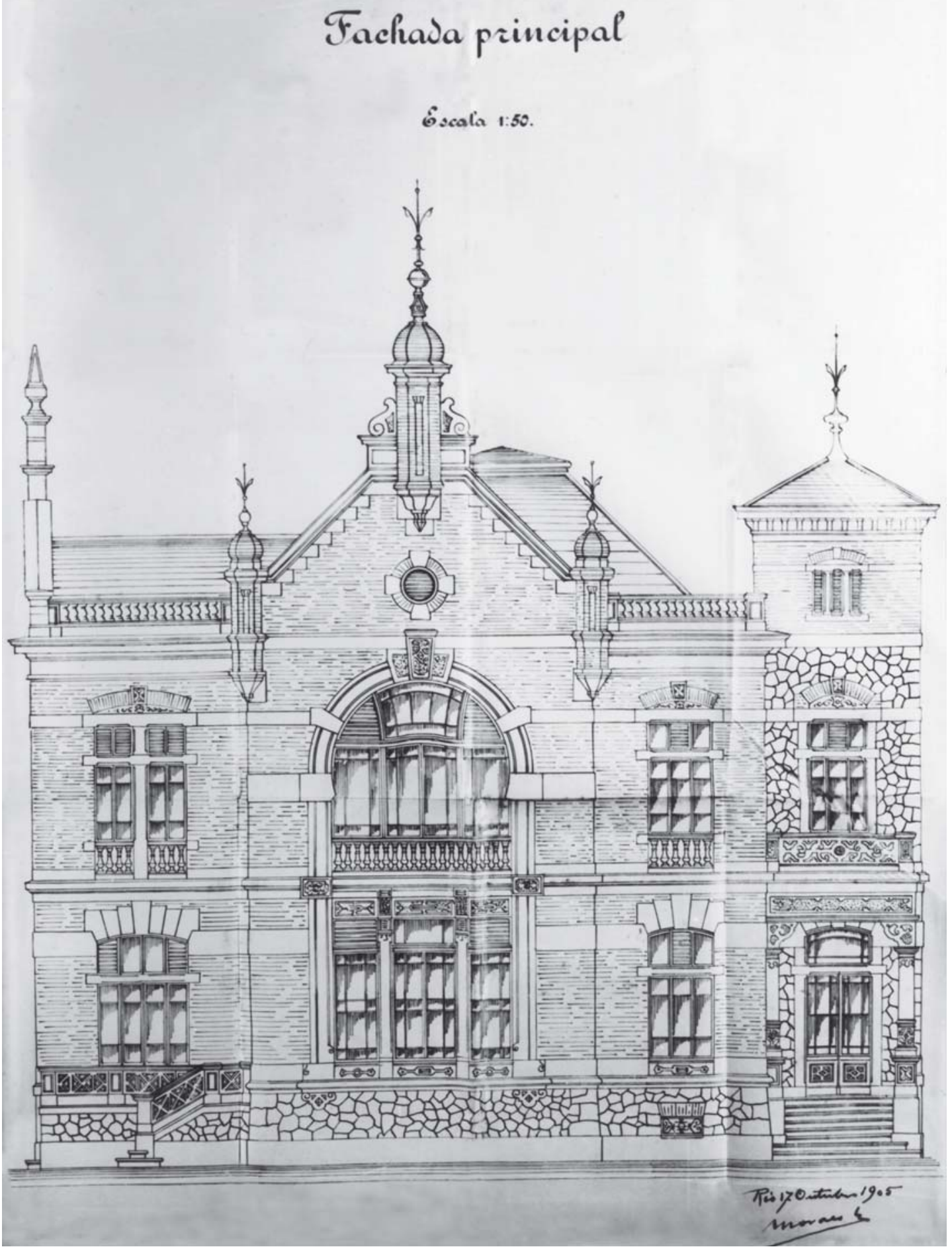

Figura 4: Fachada principal, escala 1/50 
BENEDITO TADEU DE OLIVEIRA

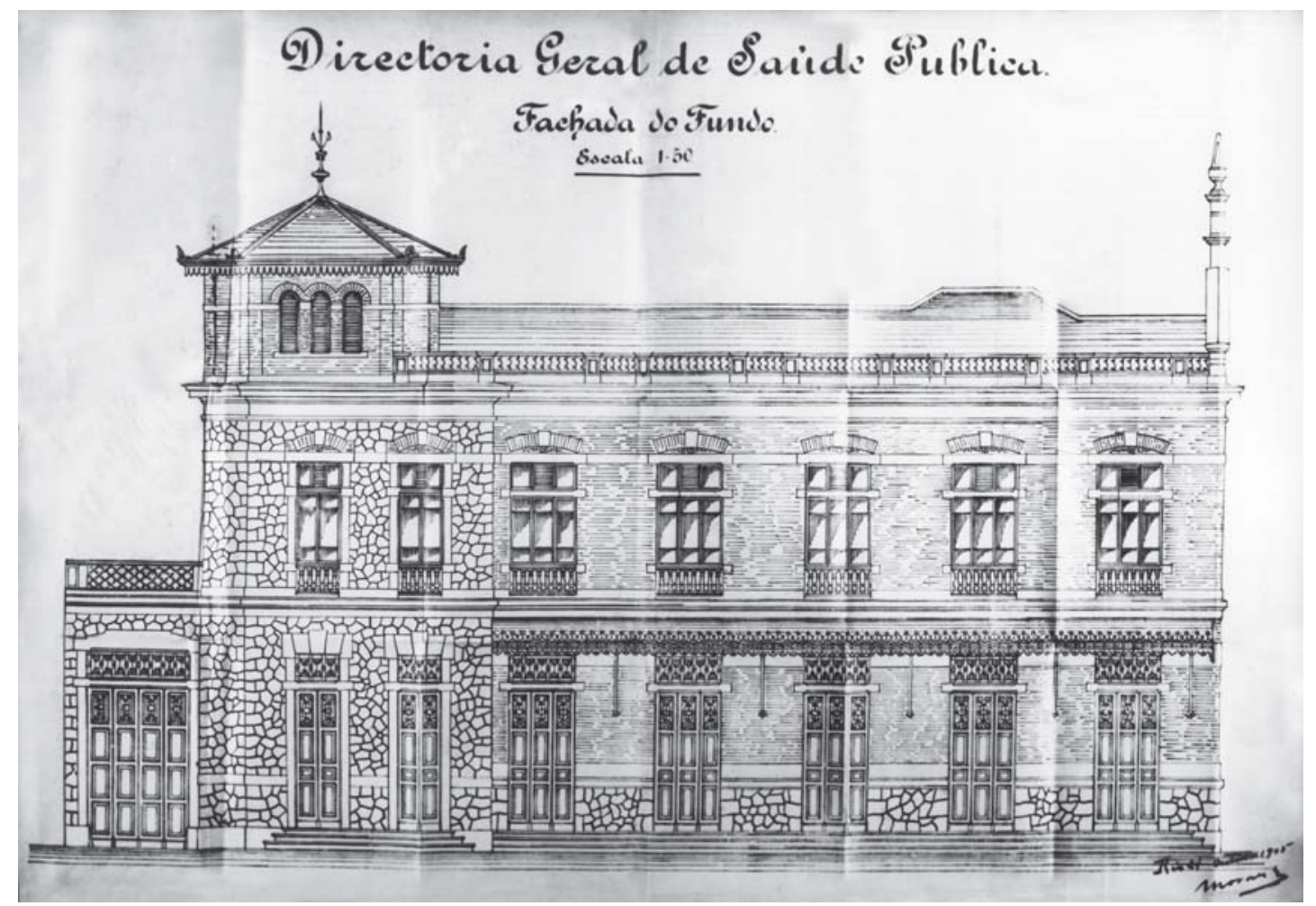

Figura 5: Fachada do fundo, escala 1/50

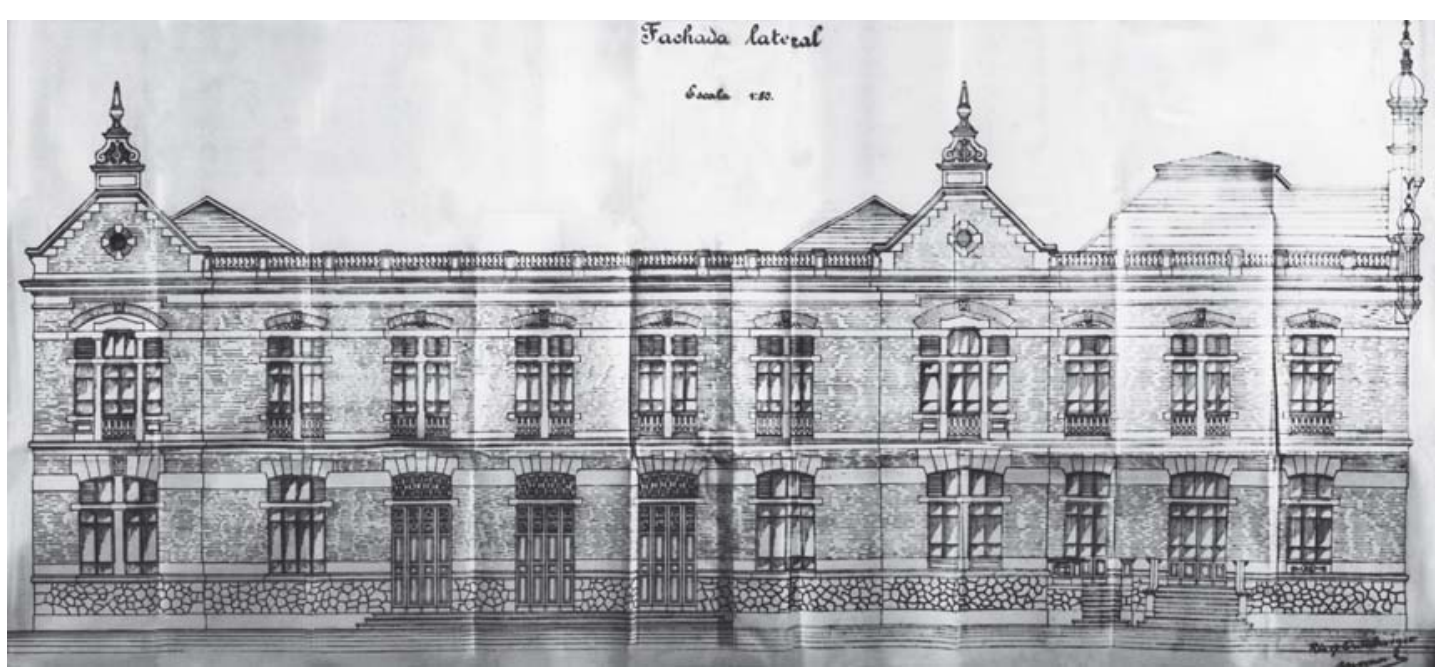

Figura 6: Fachada lateral, escala 1/50 
DA ANTIGA SEDE DA DIRETORIA GERAL DE SAÚDE PÚBLICA...

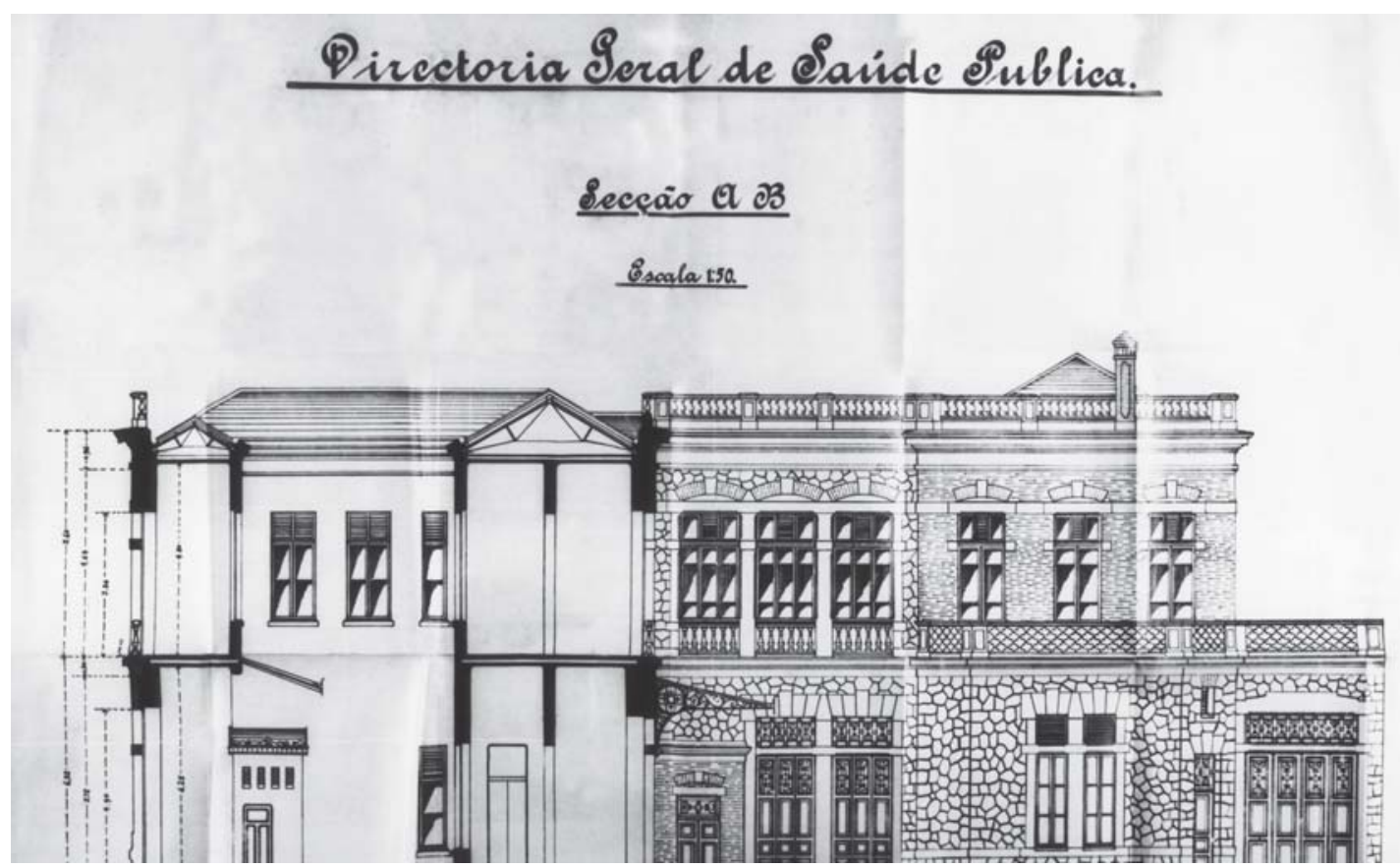

Figura 7: Seção $A B$, escala 1/50

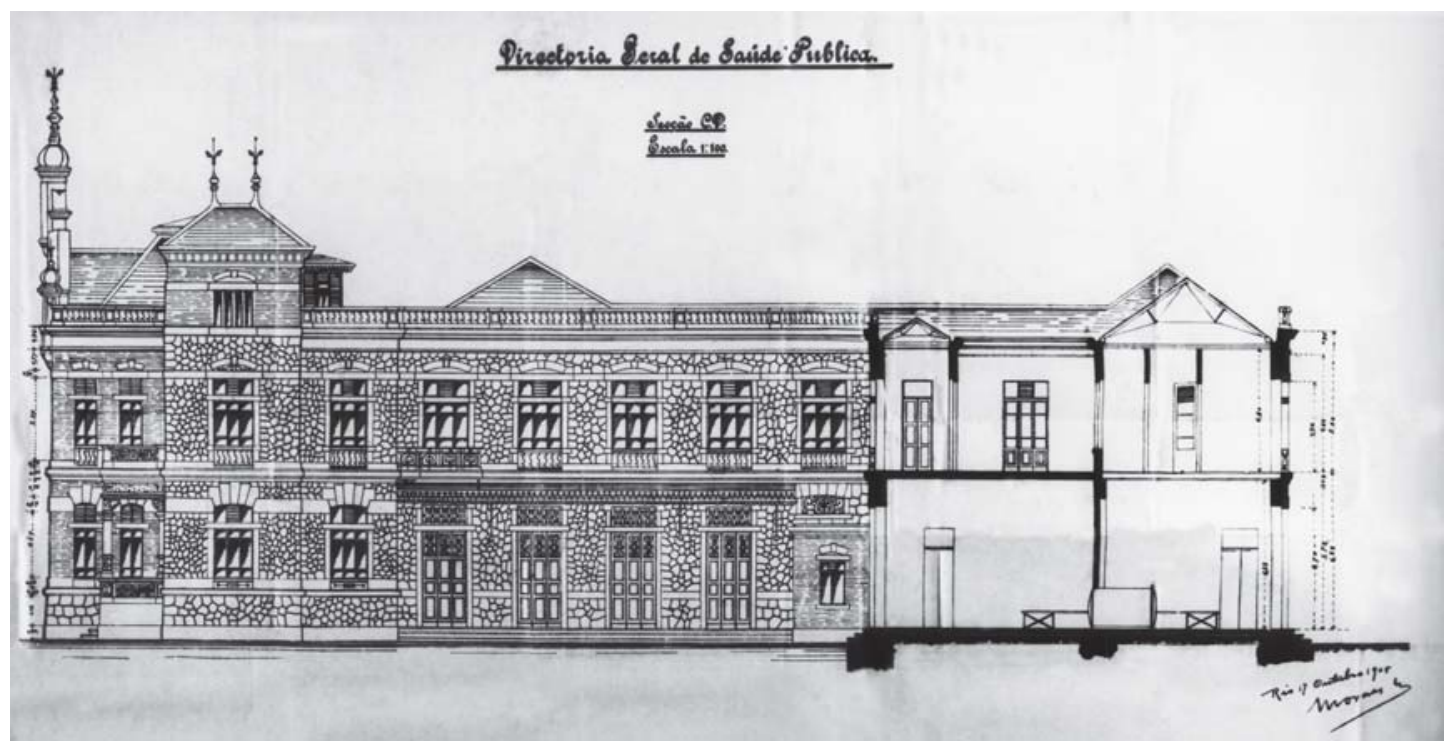

Figura 8: Seção CD, escala 1/100. 
O edifício originalmente projetado por Luiz Moraes tinha as fachadas constituídas de embasamento de pedra e eram revestidas com tijolos aparentes, coroadas por balaustradas e frontões com óculos no centro. Os vãos (portas e janelas) foram projetados com arcos rebaixados coroados por bossagens (térreo) e tijolos aparentes (primeiro andar). A maioria das janelas possuía marcação e divisão em forma de cruz, e as do primeiro andar foram projetadas com balaustradas. Constata-se nesse primeiro projeto a valorização do bloco e da fachada contígua à rua do Resende, através da marcação de sua parte mediana, utilizando amplas janelas em arco e frontão composto de torreões laterais coroados por um torreão maior. Nota-se, ainda, a utilização da pedra acima do embasamento em duas 'torres', uma na fachada principal e outra na fachada do fundo, na qual foi projetada uma marquise com estrutura metálica à semelhança da atual.

O edifício projetado tem planimetria que se desenvolve no sentido longitudinal e se articula em três blocos: o da fachada principal em forma quadrangular, ligado ao de maior dimensão com forma retangular, que se liga por sua vez a outro bloco lateral também de forma retangular, mas de menor dimensão. De estilo eclético, sua implantação utiliza recuos nos limites do terreno a fim de garantir ventilação e iluminação naturais. A relação dos espaços inicialmente projetados é a seguinte:

- Pavimento térreo: entrega de bagagem e arrecadações etc.; farmácia; depósito; lavanderias; estufas; acomodações para vestir/despir/banho; banheiros; salas de espera; lavagem de carros; serviços de turmas; secretaria; administração; arquivo; sala para os médicos; inspetoria; e portaria.

- Pavimento 1: sala para o chefe de serviço; salas de espera; biblioteca; laboratórios; terraço; culturas; autoclaves; biotérios; depósito; lavagem de vidros; vestiário; engenharia sanitária; farmacêuticas; exames de validez; procuradoria; demografia; arquivo da diretoria; museu; sala para diretor-geral; e secretaria.

Nota-se que o programa adotado era avançado para a época, pois solicitava espaços a serem equipados com modernas instalações, área para biblioteca e até mesmo para museu.

Como aconteceu em Manguinhos com a construção do Pavilhão Mourisco, esse primeiro projeto da DGSP não foi executado, muito provavelmente em conseqüência da expansão do programa original, originada da necessidade de criação de novos usos a demandarem novos espaços. Em Manguinhos o projeto original do Pavilhão Mourisco consistia em térreo e mais três pavimentos, mas o projeto definitivo foi executado com o térreo e outros cinco pavimentos. Na rua do Resende, a antiga sede da DGSP foi projetada originalmente com térreo e primeiro pavimento e executada com térreo e dois pavimentos. 
Não existem notícias sobre um projeto definitivo elaborado pelo arquiteto Luiz Moraes Júnior para a sede da DGSP. Provavelmente as alterações e retificações foram executadas durante as obras a pedido de Oswaldo Cruz, que acompanhava de perto os empreendimentos que delineava e exercia forte influência sobre o arquiteto.

Devido a falta de recursos, as obras foram praticamente paralisadas durante 1907 e prosseguiram lentamente em 1908 e 1909. Em novembro de 1909 Oswaldo Cruz deixou o cargo de diretor-geral da Saúde Pública, e em 1910 Luiz Moraes Júnior, autor do projeto, passou a direção das obras ao engenheiro sanitário e professor da Politécnica Domingos da Cunha e a seu auxiliar, o engenheiro sanitário João de Almeida Pizarro. Acompanhou a obra desde o seu início o mestre Serafim do Couto.

Para dar andamento à construção do edifício, o Congresso concedeu, em 1911, outros cem contos, duplicando a quantia em 1912 e 1913. Posteriormente essa verba foi reduzida pelo próprio Congresso Nacional, para atender a interesses públicos de outra ordem. Apesar da redução orçamentária, o sucessor de Oswaldo Cruz, Carlos Seidl, inaugurou o primeiro e o segundo pavimentos em 18 de março de 1914. A urgência da inauguração devia-se às péssimas condições higiênicas das primeiras instalações da DGSP.

A obra transcorreu durante as gestões, no Ministério do Interior, de Rivaldo Correa e seu sucessor Herculano de Freitas. A concessão do terreno deveu-se a Lauro Muller, então ministro da Viação, e aos esforços de Alfredo Graça Couto, chefe da Inspectoria dos Serviços de Profilaxia. A inauguração da antiga sede da DGSP teve a presença do presidente da República, marechal Hermes da Fonseca, e foi amplamente divulgada na imprensa da época.

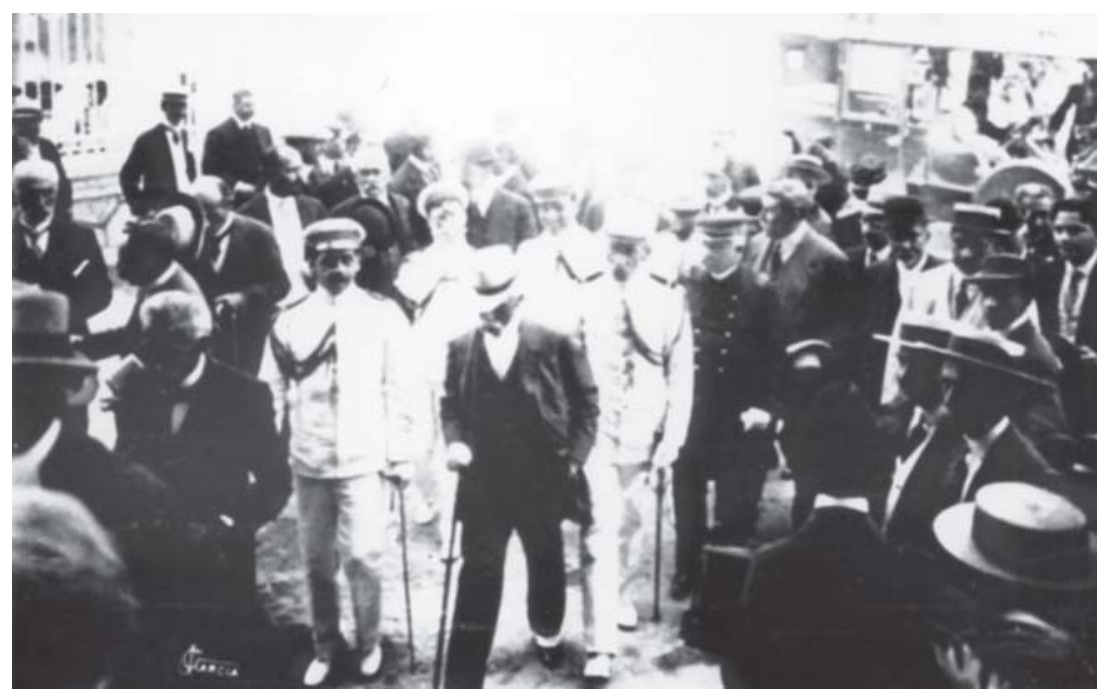

Figura 9: Revista Fon-Fon, de 1 de abril de 1914: “Aspecto tomado por occasião da visita do Presidente da República, Sr. Hermes da Fonseca, ao novo edifício da Saúde Pública” 
Segundo o Jornal do Commercio de 19 de março de 1914, o edifício recebeu as seguintes repartições: Diretoria-Geral propriamente dita, Secretaria, Arquivo, Seção Demográfico-sanitária, Seção Farmacêutica, Comissão de Exames de Validez; e Seção de Engenharia Sanitária. De acordo com o mesmo jornal, nos meses seguintes seriam transferidos para o edifício a Delegacia de Saúde, o Museu da Higiene, o Laboratório Bacteriológico e, para o andar térreo, a nova Inspectoria dos Serviços de Profilaxia. No antigo prédio da rua Clapp ficariam apenas os serviços de saúde do porto.

Ojornal A Imprensa, também do dia 19 de março, dava destaque às personalidades que compareceram à solenidade de inauguração: Rivadavia Corrêa, ministro da Fazenda; Eduardo Queiroz, ministro da Agricultura; Herculano de Freitas, ministro da Justiça; Alexandre de Alencar, ministro da Marinha; general Vespasiano de Albuquerque, ministro da Guerra; Francisco Valladares, chefe de polícia; general Souza Aguiar; Hernani Pinto; Oswaldo Cruz; e Campos Cunha.

O Paiz, sob a manchete "No palácio residencial", narrava o percurso do presidente da República, que saíra de Petrópolis às 8h30 da manhã em carro reservado de trem, em companhia dos comandantes Jorge da Fonseca, subchefe da Casa Militar da Presidência, Euzébio Queiroz Mattoso e Mário Pimentel Brandão, oficiais de gabinete e ajudantes de ordens. O jornal relatava que o presidente da República dirigira-se para o novo edifício da Diretoria-Geral de Saúde Pública em automóvel oficial, acompanhado de Herculano de Freitas e do general Barbedo.

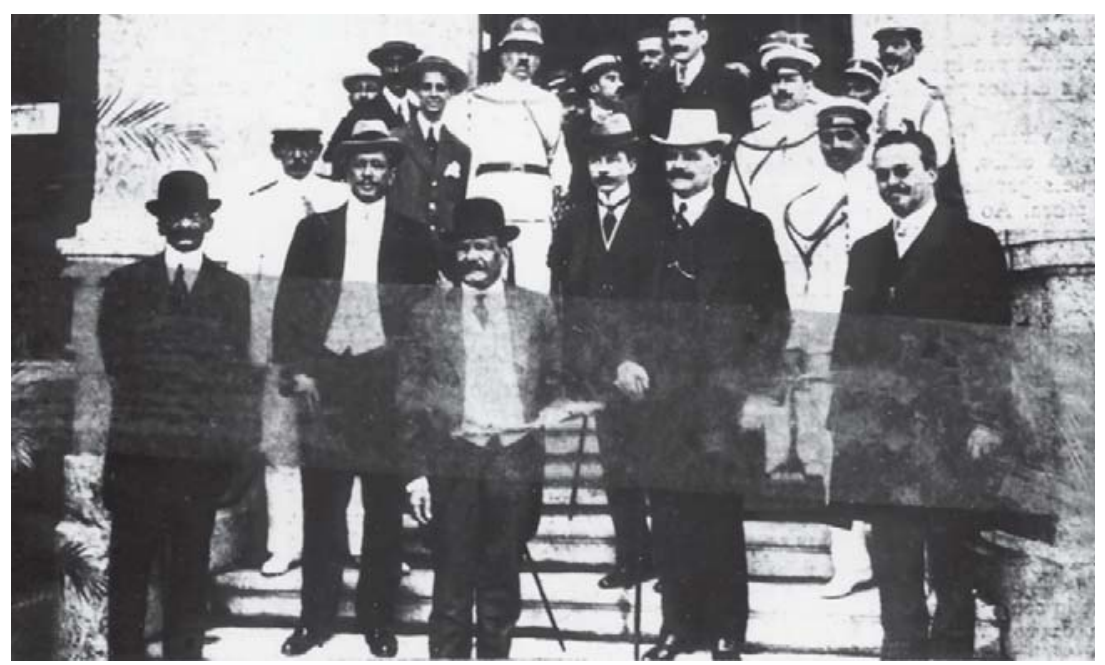

Figura 10: Revista Fon-Fon, de 1ำ de abril de 1914. “O Sr. Hermes da Fonseca, Presidente da República, seus ministros Dr. Eduardo de Queiroz, Ministro da Agricultura, Dr. Herculano de Freitas, Ministro da Justiça e Dr. Rivadávia Corrêa, Ministro da Fazenda. O Sr. Chefe de Polícia Dr. Francisco Valladares, o Dr. Carlos Seidl, Diretor Geral da Saúde Pública e outras pessoas que assistiram a inauguração" 
A inauguração do edifício foi noticiada também pelas revistas Saúde Pública e Illustração Brasileira, n.117, de 1º de abril de 1914.

Apesar do acréscimo de um pavimento, a construção manteve a linguagem formal proposta por Luiz Moraes Júnior, a implantação inicial, o desenho dos vãos projetados inicialmente e a valorização do bloco contíguo na rua do Resende. As fachadas do pavimento acrescentado durante a execução das obras têm fortes semelhanças com a fachada do primeiro pavimento. No entanto algumas alterações foram feitas, entre as quais se destacam:

- O frontão da fachada principal foi construído sem o torreão de coroamento, e os dois torreões menores foram deslocados lateralmente para delimitar as iniciais DGSP;

- O 'bloco' contíguo à rua do Resende continuou destacado do restante do edifício e foi revestido totalmente de cantaria;

- Diminuíram-se as áreas do telhado e aumentaram-se as áreas de terraço;

- As fachadas laterais e do fundo, projetadas anteriormente para serem revestidas em cantaria e na sua maior extensão em tijolos aparentes, foram revestidas de argamassa;

- Instalou-se um elevador, não previsto no projeto original, para auxílio na circulação vertical.

Cabe ressaltar que Luiz Moraes utilizou, no edifício da sede da DGSP, repertório formal, sistemas construtivos e materiais de construção muito semelhantes àqueles utilizados no conjunto arquitetônico histórico de Manguinhos, dos quais os principais são:

- Os torreões de coroamento da fachada principal da antiga sede da DGSP voltada para a rua do Resende foram executados em granito e tijolos de Marselha aparentes, e os torreões da fachada posterior do Pavilhão Mourisco em Manguinhos foram feitos em cimento, areia e tijolos de Marselha aparentes. Os desenhos e aspectos desses elementos arquitetônicos são muito semelhantes;

- Sobrevergas com tijolos de Marselha aparentes e granito, tanto nas janelas da sede da DGSP quanto nas janelas do Pavilhão da Cavalariça em Manguinhos;

- Escadas de ferro e mármore e clarabóias tanto no hall de entrada da sede da DGSP quanto no hall central do Pavilhão Mourisco em Manguinhos;

- Embasamento de granito com desenhos irregulares, tanto na antiga sede da DGSP quanto no Pavilhão do Relógio em Manguinhos;

- A mureta da entrada da sede da DGSP, na rua Washington Luís, foi construída em cimento e areia utilizando-se motivos 
'naturalistas', como também o corrimão da escada da torre central do biotério para pequenos animais, conhecido como Pombal, em Manguinhos;

- O sistema construtivo adotado na edificação da sede da DGSP consistiu na utilização de fundação corrida de pedra, cimento e areia, os chamados cafofos, sobre os quais foram erguidas paredes portantes de alvenaria de pedra e tijolos; o mesmo sistema construtivo foi adotado nos Pavilhões Mourisco, do Relógio e da Cavalariça, em Manguinhos;

- Na cobertura da sede da DGSP, adotou-se a solução de terraços pavimentados com cerâmica de Marselha, constituídos de lajes estruturadas em vigas metálicas, com seus vãos preenchidos com tijolos furados. Nas construções sobre os terraços utilizaram-se coberturas de telhas francesas de Marselha sobre estruturas de madeira. A solução de terraços pavimentados com cerâmica de Marselha também foi adotada no Pavilhão Mourisco, e as coberturas de telhas francesas de Marselha sobre estruturas de madeira foram utilizadas nos Pavilhões do Quinino e do Relógio, em Manguinhos;

- Entre os materiais de construção utilizados tanto na rua do Resende quanto em Manguinhos destacam-se a madeira e o granito nacionais, além de telhas, tijolos e cerâmicas de piso provenientes de Marselha, na França, e aço, esquadrias e azulejos da marca Villeroy-Bosch, originários da Alemanha.

Em linhas gerais pode-se afirmar que Luiz Moraes Júnior e Oswaldo Cruz realizaram, na rua do Resende, um primeiro ensaio do empreendimento maior que estava sendo executado paralelamente em Manguinhos.

Não foram encontrados registros do projeto definitivo do edifíciosede da DGSP, assim como os projetos dos edifícios anexos. Porém, já no dia da inauguração da sede da Diretoria, o Jornal do Commercio assinalava a necessidade de construção de edifícios anexos destinados à guarda de material e de uma garagem para automóveis de serviço, que aos poucos vinham substituindo os veículos de tração animal utilizados para atender os subúrbios e as zonas rurais do Distrito Federal. O mesmo jornal apontava a necessidade de incorporar ao terreno do edifício o lote contíguo à esquerda, para isolar de futuras construções privadas o desinfectório e o biotério do Laboratório Bacteriológico. Com efeito, a imagem de capa da publicação do Departamento Nacional de Saúde Pública, denominada Archivos de Hygiene, ano 1, n.1, de 1927, destacava a incorporação ao DGSP dos terrenos vizinhos do lado esquerdo de sua sede. Na mesma fotografia constata-se, também, a existência de um canteiro central arborizado, no atual pátio interno pavimentado com paralelepípedos do conjunto arquitetônico da rua do Resende. 
A primeira imagem dos edifícios anexos está documentada no levantamento denominado "Mosaico fotográfico - Distrito Federal" (escala 1:1000), folha 25, de agosto de 1928, de autoria de The Aircraft Operating Co. Ltd., atualmente sob a guarda do Arquivo Geral da Cidade do Rio de Janeiro (AGCRJ).

As mesmas imagens aparecem também no levantamento cadastral de 1929, impresso pela mesma companhia inglesa, e no levantamento de 1930, que indica os melhoramentos em execução pela administração Antonio Prado Júnior e faz parte hoje do acervo do Instituto Pereira Passos.

Essas imagens nos revelam não só a presença dos edifícios que hoje abrigam o Centro de Reabilitação e a Coordenação de Ensino e Divulgação Científica (CEDC), como também os edifícios situados nos limites da rua Washington Luís. A imagem original do 'mosaico fotográfico' é de excelente qualidade, e nela identificam-se os pátios externos e internos, a arborização da época e o entorno dos edifícios do então Departamento Nacional de Saúde Pública.

Nos edifícios anexos foram utilizados materiais de construção de qualidade inferior e sistemas construtivos menos sofisticados do que os utilizados na sede da DGSP, mas adotou-se "uma arquitetura de acompanhamento", o que revela forte presença e influência da antiga sede da DGSP sobre seu entorno.

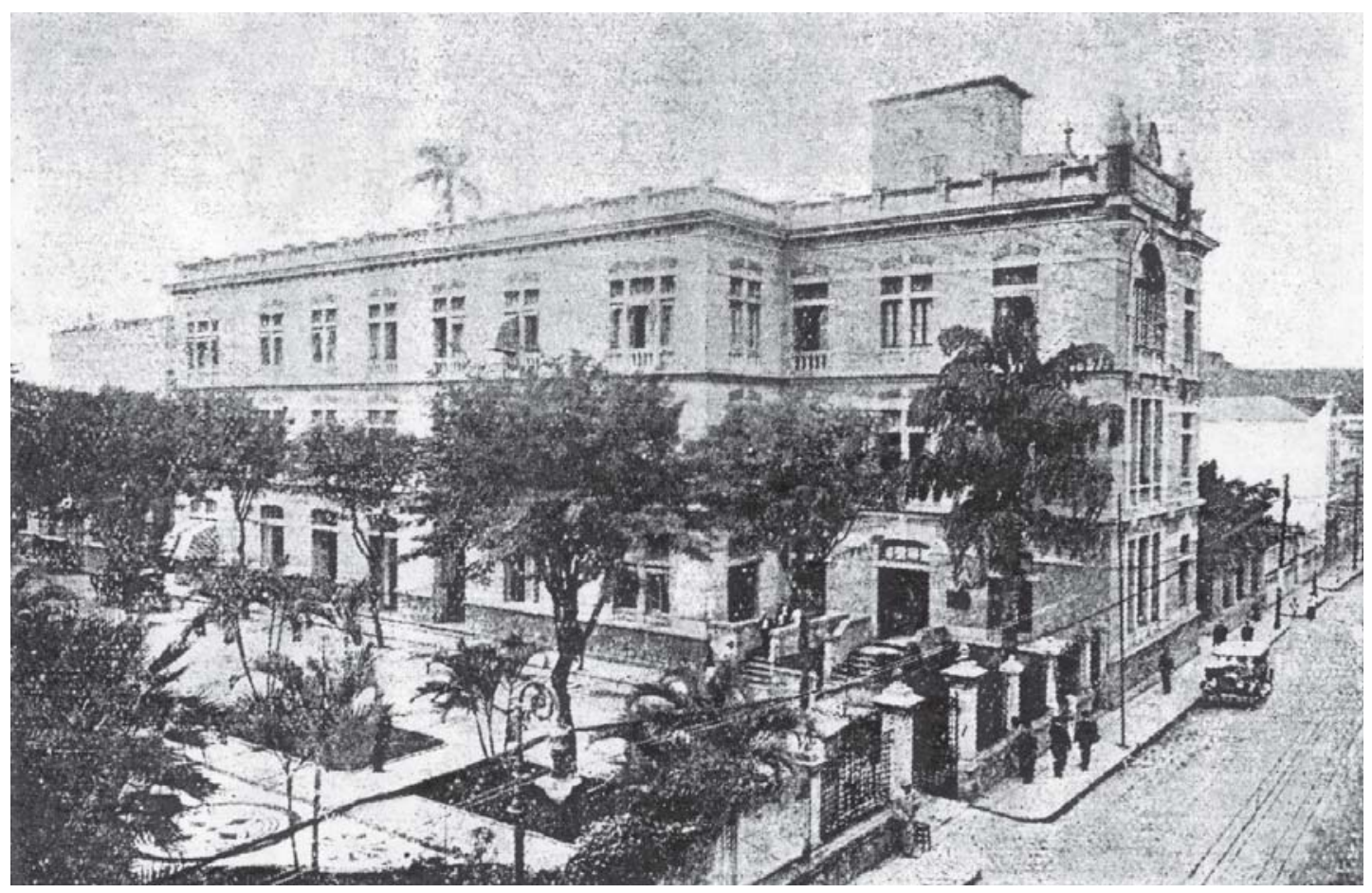

Figura 11: Edifício-sede da Saúde Pública, à rua do Resende. Capa da publicação Archivos de Hygiene, ano I, n.l, de 1927 
O mesmo número já mencionado de Archivos de Hygiene nos revela quatro imagens do interior do edifício, onde se vêem diversas atividades do Laboratório Bacteriológico. Constata-se ainda a preocupação constante no sentido de melhorar e expandir as instalações e os espaços destinados a cuidar da saúde pública. Transcrevemos a seguir alguns pontos de vista da revista:

Verificada a palpável insuficiência das instalações e recursos do Laboratório Bacteriológico, aplicou a atual administração seus primeiros esforços em dotar dos necessários melhoramentos esta pedra angular de um moderno serviço de Saúde Pública.

Foi dilatada a área das instalações, acrescentando-se-lhe nove compartimentos, retirados a outros serviços, transferidos para locais mais apropriados, e, terminados os trabalhos de limpeza e pintura geral, foi possível cuidar de tornar-lhe o aparelhamento consentâneo com o aperfeiçoamento da técnica com o desejável aumento da capacidade de produção

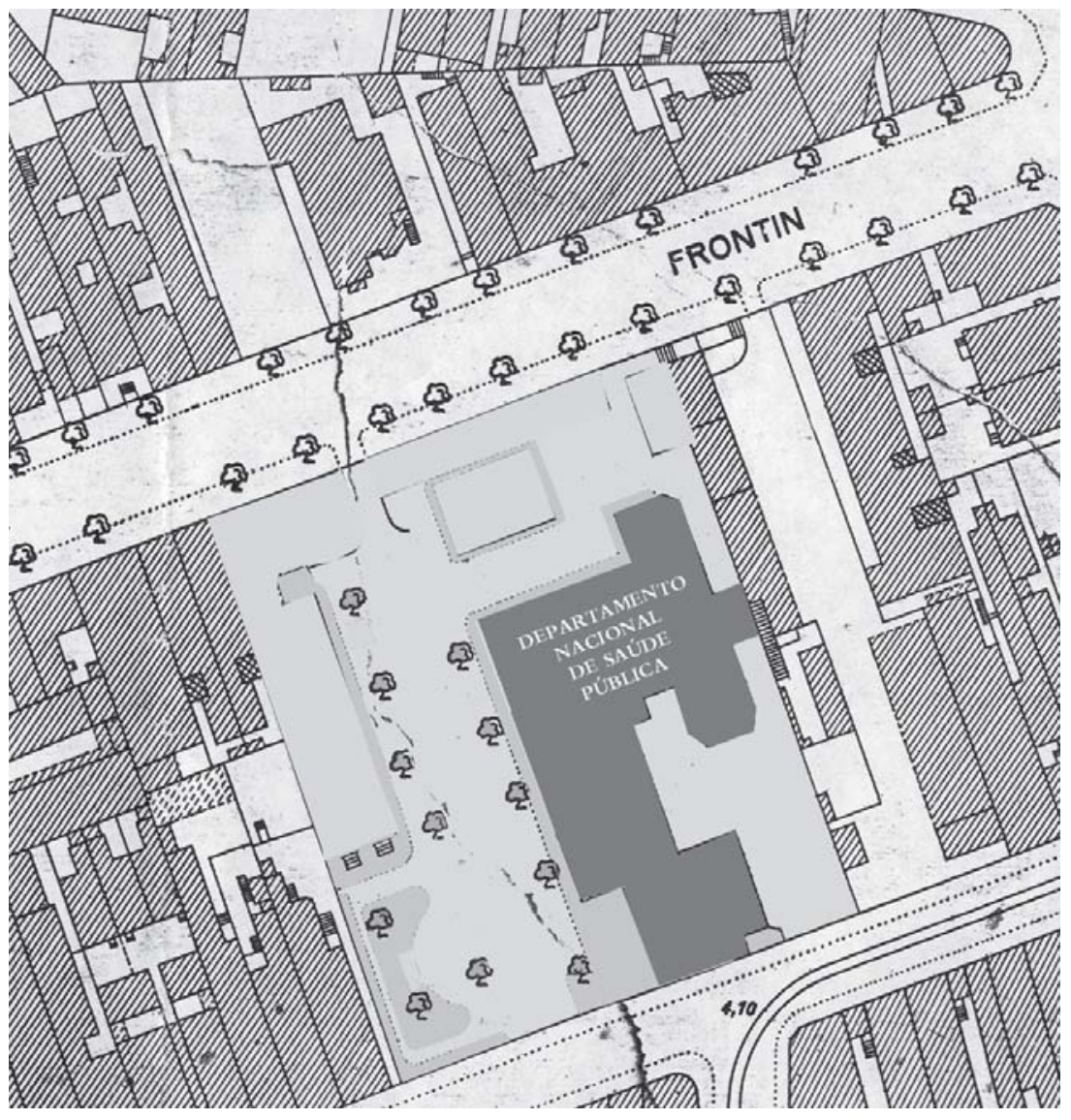

Figura 12: Levantamento cadastral de 1930. A edificação do Departamento Nacional de Saúde Pública, antiga DGSP, com seus edifícios anexos voltados para o pátio interno e para a rua Paulo de Frontin, atual Washington Luís. Instituto Pereira Passos 
Dentro de curto lapso começaram a funcionar as seguintes novas dependências:

a) Laboratório de Bacteriologia

b) Laboratório de Anatomia Patológica

c) Sala de esterilização e de preparo de meios de cultura

d) Seção de balanças de precisão

e) Capela para trabalhos com desprendimento de gases irritantes f) Aperfeiçoamento da iluminação.

(Archivos..., 1927; grafia atualizada)

Em outro trecho da mesma publicação lê-se:

Por determinação do Sr. Dr. Diretor foi feito o revestimento de azulejo das paredes do Dispensário Central desta Inspetoria e a pintura dele, o que muito contribuiu para melhorar as condições de higiene e também a sua estética, coisa que não é indiferente nas obras de saúde pública.

Em relatório de 1928 do professor Clementino Fraga, então diretor-geral do Departamento de Saúde Pública, dirigido ao ministro, observamos as mesmas preocupações quanto à necessidade de "ampliação administrativa, desenvolvimento técnico do Departamento Nacional de Saúde Pública e de reparos indispensável no edifício central".

Em 1939, o centro de saúde passou da esfera federal para a municipal. Nos anos seguintes abrigou o serviço materno-infantil, de

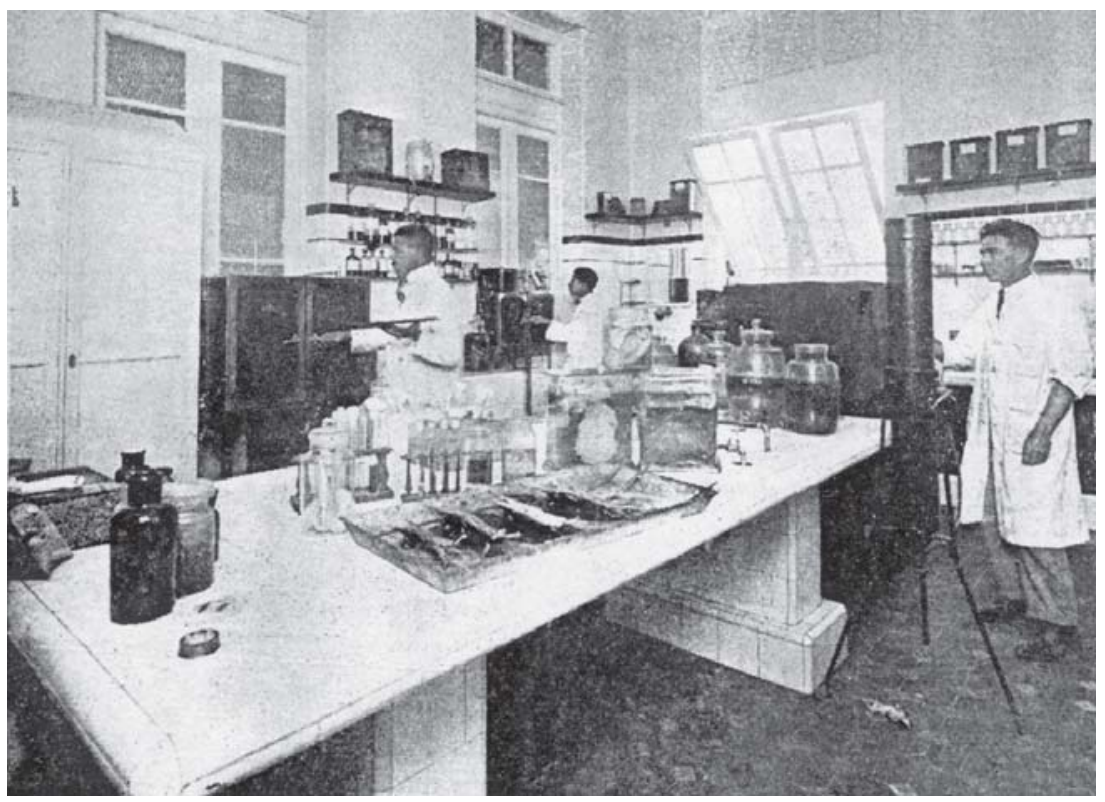

Figura 13: Laboratório Bacteriológico - Gabinete de Anatomia Patológica. Ilustração Brasileira, n.117, de 1ํ de abril de 1914 
epidemiologia, prevenção do câncer ginecológico, pré-natal, prénupcial, de medicina escolar, de dermatologia e doenças venéreas e de pneumologia sanitária. Atestam as constantes reformas executadas na antiga sede da Diretoria de Saúde Pública um conjunto de plantas baixas (escala 1:50) encontradas no Arquivo da Companhia Estadual de Águas e Esgotos (Cedae) e aprovadas em 27 de abril de 1950.

Na década de 1950 o centro de saúde passou a se chamar Centro de Saúde Oswaldo Cruz. No levantamento cadastral de 1953 (escala 1:1000), nota-se a presença de novos anexos. A sigla PM aposta ao documento indica a subordinação do órgão à Prefeitura Municipal da Cidade do Rio de Janeiro Já no levantamento de 1975 (escala 1:2000), de menor precisão, identificam-se novos usos relacionados ao Instituto Nacional de Tuberculose.

Atualmente o edifício abriga a Coordenação de AdministraçãoGeral (Coage) e o Centro de Reabilitação do Instituto Nacional de Câncer (Inca).

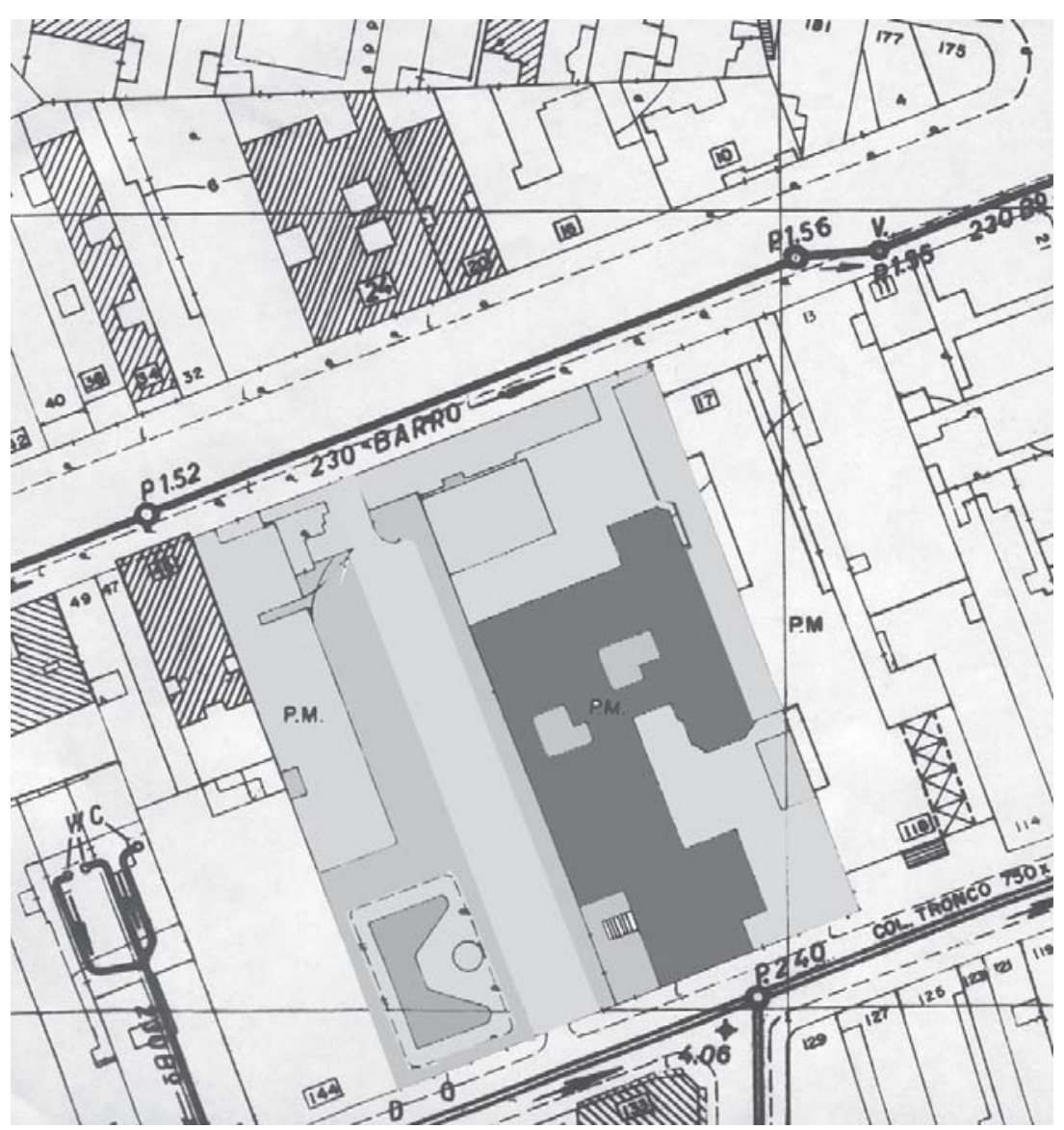

Figura 14: Levantamento cadastral de 1953 (escala 1:1000). Nota-se o adensamento do lote por meio do aumento dos edifícios anexos. AGCRJ 


\section{Sobre o engenheiro Luiz Moraes Júnior}

O Jornal do Brasil de 16 de julho de 1955 publicou uma longa nota de falecimento de Luiz de Moraes Junior, "ilustre engenheiro sanitarista", que falecera aos 85 anos. O necrológio publicado pelo jornal dá bem a medida da importância do engenheiro, embora não seja preciso nas suas informações. No mais completo estudo biográfico de Luiz Moraes Júnior e da sua obra, Jaime Benchimol (1990, cap. 3) informa ter o engenheiro nascido a 28 de janeiro de 1868, tendo falecido, portanto, com 87 anos de idade.

Luiz Moraes graduou-se em engenharia em Lisboa e iniciou sua carreira profissional como engenheiro ferroviário. Imigrou para o Brasil em 1900, a convite do padre Ricardo, vigário-geral da Igreja da Penha, para executar obras de reestruturação e embelezamento das fachadas que foram concluídas em 1902. Suas principais realizações como arquiteto e construtor ocorreram sob os auspícios e durante a curta trajetória de Oswaldo Cruz, que o conheceu nos percursos diários de trem que faziam até a estação do Amorim. Na ocasião, Oswaldo Cruz se dirigia para Manguinhos e Luiz Moraes para a Penha.

No período de 1902 a 1917 Luiz Moraes Júnior acumulou notável experiência na projetação [sic] e na coordenação de construções de edifícios destinados a abrigar instalações sanitárias, hospitalares e laboratoriais. Destaca-se nesta área o projeto de 1904, em estilo neo-renascentista alemão, da sede da Policlínica na avenida Central, atual Rio Branco.

Outro projeto de grande importância na área da saúde pública foi o da Faculdade de Medicina da Praia Vermelha, de 1914, construído pela firma do arquiteto Antônio Januzzi e destruído pela Eletrobrás durante o governo Geisel, em 1975. Entre 1904 e 1922 Luiz Moraes projetou e coordenou a construção de sua obra mais significativa, que é o conjunto arquitetônico histórico de Manguinhos - Fiocruz, em estilo eclético e formado de: Pavilhão Mourisco, Pavilhão da Peste, Pavilhão Vacinogênico, Pavilhão da Cavalariça, Quinino, Pombal, Aquário (demolido) e Hospital Evandro Chagas. São ainda de sua autoria os projetos do desinfectório de Botafogo, atual Hospital Rocha Maia, iniciado em 1904 e concluído no ano seguinte, e o do sanatório para tuberculosos de Mendes, de 1914.

Em Belo Horizonte, Luiz Moraes projetou as obras de ampliação e adaptação do edifício da Intendência da Força Pública para abrigar a filial do Instituto Soroterápico de Manguinhos em Minas Gerais. A obra, situada em quadra com uma face voltada para praça da Liberdade, foi inaugurada no dia 3 de agosto de 1907. Em 1919 o arquiteto projetou no mesmo terreno um Serpentário, cuja solução arquitetônica muito se assemelha à do Biotério para Pequenos Animais de Manguinhos, popularmente chamado de Pombal. Estas edificações foram demolidas por volta da década de 1950, para dar lugar ao Centro de Educação Permanente Professor Luiz de Bessa, edifício projetado pelo arquiteto Oscar Niemeyer em 1954 (Oliveira et al., 2003).

Luiz Moraes atuou também na área de construções residenciais, dentre as quais se destacam: residência de Oswaldo Cruz em Botafogo (demolida), palacete em estilo parisiense na praia do Flamengo, o Rio Hotel na Praça Tiradentes e, em Petrópolis, sua residência particular, o prédio do Grande Hotel e o prédio do jornal Tribuna de Petrópolis. Em Belo Horizonte, Luiz Moraes projetou o Parc Royal, na rua da Bahia no 894, protegido desde 1994 pela Secretaria Municipal de Cultura e hoje ocupado pela Caixa Econômica Federal.

São estas as principais características dos projetos de Luiz Moraes Júnior: consonância com as tendências formais e estéticas da época, grande habilidade na combinação de elementos arquitetônicos e de estilos do passado, independência entre programas e concepções formais, apuro estético resultante da escolha de materiais de construção 'nobres' e da qualidade das técnicas construtivas empregadas. 


\section{O processo de tombamento do edifício da DGSP}

As primeiras iniciativas para a proteção da antiga sede da DGSP datam de 1953. Partiram do deputado pela Paraíba Junduí Carneiro, que elaborou o projeto de lei $n^{\circ} 3.803$, no qual solicita e justifica o tombamento. O Diário de Notícias de 15 de maio daquele ano relatava a importância e o valor histórico da edificação, "cujo renome internacional, nos domínios da ciência, Oswaldo Cruz engrandeceu".

Esse projeto de lei deu origem, na então Diretoria de Patrimônio Histórico e Artístico Nacional (Dphan), atual Instituto de Patrimônio Histórico e Artístico Nacional (Iphan), ao processo ${ }^{\circ}$ 105.355, de 1953, e teve parecer negativo do Conselho Consultivo. O órgão entendeu que o edifício não possuía "excepcional valor artístico" nem estava diretamente vinculado a "fatos memoráveis da história do Brasil", tal como preceitua a lei ao estabelecer as condições de tombamento. Portanto não se constituía razão suficiente para determinar seu tombamento na categoria de monumento histórico. Em decisão surpreendente, a Dphan optou pelo tombamento da casa natal de Oswaldo Cruz, em São Luís do Paraitinga, no estado de São Paulo. Não elegeu como edificação mais representativa da memória de Oswaldo Cruz o conjunto arquitetônico histórico de Manguinhos, sua principal obra, nem mesmo o prédio da DGSP, e sim a modesta residência onde nasceu o cientista. Nota-se que, na política de preservação de bens culturais da então Dphan, os edifícios do período eclético não eram considerados tão importantes quanto os do período colonial. Tal linha de atuação, que valorizava um estilo em detrimento de outro, facilitou a destruição de parte significativa da arquitetura dos períodos neoclássico e eclético das médias e grandes cidades brasileiras.

O projeto de tombamento do DGSP foi retomado em 18 de janeiro de 1983 pelo médico Luiz Carlos Bevilaqua, então diretor do Centro Municipal de Saúde Oswaldo Cruz, da 2 ${ }^{2}$ Região Administrativa, que encaminhou ofício e abaixo-assinado dos funcionários daquele órgão ao professor Manuel Diegues Júnior, diretor do Instituto Estadual de Patrimônio Cultural do Estado do Rio de Janeiro (Inepac). A importância arquitetônica, histórica e cultural da antiga sede da DGSP foi reconhecida pelo Inepac através de tombamento provisório de 13 de fevereiro de 1989, e pelo tombamento definitivo de 7 de março de 1991 (Inepac, 1983/1991). Atualmente a antiga sede da DGSP encontra-se em razoável estado de conservação, mas poderia ter sido preservada mais integralmente, nos seus aspectos estéticos, históricos e ambientais, se o projeto de tombamento encaminhado em 1953 à então Dphan tivesse sido aprovado.

Cabe à atual administração do Inca a recuperação e preservação da antiga sede da DGSP e dos seus edifícios anexos, obedecendo aos princípios modernos da restauração. Há, portanto, necessidade 
Agradecimentos

Ao Instituto Nacional do Câncer (Inca), pelo apoio recebido através do Setor de Produção de Material Educativo/ Coordenação de Ensino e Divulgação Científica (CEDC) e da Divisão de Engenharia/ Coordenação de Administração-Geral (Coage).

A publicação deste artigo não seria possível sem o trabalho de coleta de dados, consultas e pesquisas em arquivos e bibliotecas públicas, realizado pela arquiteta Ana Helena Seaunez Salgado. de desenvolver um projeto de restauração que tenha como etapas iniciais a elaboração de um rigoroso levantamento arquitetônico, o mapeamento de danos, a análise dos materiais de construção, diagnósticos das causas de deterioração, proposta de novos usos e identificação dos sistemas construtivos e das diversas transformações pelas quais passou o conjunto arquitetônico da rua do Resende ao longo dos anos. Esses trabalhos são essenciais para a elaboração de uma metodologia de intervenção e de um projeto completo de restauração contemplando as seguintes intervenções: recuperação dos terraços; tratamento e reforço de estruturas; recuperação de azulejos; pintura de acordo com as cores originais; recuperação e preenchimento das lacunas dos ornamentos originais; restauração das clarabóias, esquadrias metálicas e de madeira; substituição das instalações hidro-sanitárias e elétricas; iluminação monumental, tratamento do entorno; e instalação de sistemas de ar-condicionado central adaptados a edificações tombadas. São ações indispensáveis para a restauração e conservação desse precioso bem cultural da cidade e do estado do Rio de Janeiro, um dos pontos de referência da origem, evolução e institucionalização das políticas de saúde pública brasileiras.

\section{ARQUIVOS, BIBLIOTECAS E INSTITUIÇÕES CONSULTADAS}

Academia Nacional de Medicina; Arquivo da Cedae; Arquivo da Light; Arquivo do Itamarati; Arquivo Geral da Cidade do Rio de Janeiro; Arquivo Nacional; Arquivo Público do Rio de Janeiro; Biblioteca Nacional; Biblioteca do Ministério da Fazenda; Clube de Engenharia; Fundação Getúlio Vargas; Fundação Oswaldo Cruz; Instituto Histórico e Geográfico Brasileiro; Instituto Pereira Passos; Prefeitura da Cidade do Rio de Janeiro; Secretaria Municipal de Urbanismo do Rio de Janeiro (Irajá).

\section{REFERÊNCIAS DOCUMENTAIS E BIBLIOGRÁFICAS}

Archivos...

1927

Benchimol, Jaime L. (Coord.)

1990

Carvalho, José Murilo de 2000

Coaracy, Vivaldo 1988

Cruz, Oswaldo 1906
Archivos de Hygiene. Rio de Janeiro, ano 1, n.1.

Manguinhos do sonho à vida: a ciência na Belle Époque.

Rio de Janeiro: Casa de Oswaldo Cruz/Fiocruz.

Os bestializados: o Rio de Janeiro e a República que não foi.

São Paulo: Companhia das Letras

Memórias da cidade do Rio de Janeiro. Belo Horizonte: Itatiaia; São Paulo: Edusp.

Relatório apresentado ao Exmo. Sr. J. J. Seabra, Ministro da Justiça e Negócios Interiores, pelo Dr. Oswaldo Gonçalves Cruz, DGSP - 1905.

Rio de Janeiro: Imprensa Nacional. 
BENEDITO TADEU DE OLIVEIRA

Gerson, Brasil

2000

Inepac

$1983 / 1991$

Oliveira et al.

2003

Relatórios... 1906

Relatórios... 1905
História das ruas do Rio (e da sua liderança na história política do Brasil). Rio de Janeiro: Nova Aguilar.

Processo de tombamento do centro municipal de saúde Oswaldo Cruz. Rio de Janeiro. Processo n. E-18/3000.28/84. (Inepac)

Oliveira, Benedito T. (Coord.); Costa, Renato da G.R.; Pessoa, Alexandre J. de S. Um lugar para a ciência: a formação do campus de Manguinhos. Rio de Janeiro: Ed. Fiocruz.

Biblioteca Nacional, Relatórios Ministeriais de 1906. Ministério da Justiça e Negócios Interiores, v.5. S.1. (Biblioteca Nacional).

Relatórios ministeriais de 1905. Ministério da Justiça e Negócios Interiores, v.5. S.1. (Biblioteca Nacional).

Recebido para publicação em julho de 2003.

Aprovado para publicação em outubro de 2006. 